\title{
O. ROMUALD GUSTAW OFM - ZALOŻYCIEL OŚRODKA ARCHIWÓW BIBLIOTEK I MUZEÓW KOŚCIELNYCH
}

O. Romuald Gustaw OFM jest powszechnie znany jako długoletni dyrektor Biblioteki Uniwersyteckiej KUL, którą uczynił jedną z najważniejszych książnic w Polsce. Jednak jego działalność nie skupiała się tylko organizowaniu i prowadzeniu książnicy. Drugą ważną dziedziną jego aktywności była akcja szkoleniowa dla bibliotekarzy i kandydatów do tej pracy. Z tego nurtu zrodził się pomysł stworzenia Ośrodka Archiwów, Bibliotek i Muzeów Kościelnych. Wszystkie te działania były próbą zniwelowania negatywnych skutków drugiej wojny światowej, która przyniosła niepowetowane straty w kościelnych zbiorach kulturowych oraz wśród pracowników kościelnych instytucji. Dodatkowo, nowe władze komunistyczne ograniczały działalność Kościoła katolickiego także w sferze kulturalnej i naukowej, co skutkowało zerwaniem współpracy między instytucjami państwowymi i kościelnymi.

Idąc naprzeciw tym potrzebom, w 1953 r. prymas Stefan Wyszyński zwrócił się do dyrektora Biblioteki KUL o. Romualda Gustawa OFM ${ }^{1}$ o pomoc w orga-

*Artur Hamryszczak - dr historii, asystent naukowy w Ośrodku Archiwów Bibliotek i Muzeów Kościelnych KUL, e-mail: artur.hamryszczak@kul.pl

${ }^{1}$ Gustaw Romuald OFM (Michał Antoni) - ur. 5 stycznia 1911 r. w Zbarażu, zm. 14 stycznia 1976 r. w Lublinie, historyk Kościoła, bibliotekarz i bibliograf. Do zakonu wstąpił 1926 r., w 1936 r. przyjął święcenia kapłańskie. W tym samym roku uzyskał magisterium z teologii na Uniwersytecie Jana Kazimierza we Lwowie, w 1947 r. na KUL - doktorat na podstawie pracy Kościół i klasztor św. Józefa sióstr bernardynek w Krakowie i w 1964 r. habilitację za pracę „Rozwój pojęcia historii Kościoła od I do XVIII wieku. W 1971 r. został docentem historii Kościoła na KUL. Pełnił różne funkcje zakonne, m.in. w latach 1936-1950 był generalnym archiwistą i bibliotekarzem prowincji bernardynów polskich. W okresie II wojny światowej był przełożonym klasztoru w Krakowie. Pełnił funkcję wice-postulatora (1949-1950) w procesach kanonizacyjnych bł. Jana z Dukli i bł. Szymona z Lipnicy. W 1950 r. został dyrektorem Biblioteki KUL. W latach 1950-1953 wykładał na KUL bibliotekoznawstwo, a od 1958 metodykę pracy naukowej, prowadził również cykle wykładów w ramach szkolenia pracowników Biblioteki KUL. W latach 1974-1975 zorganizował dwuletni międzywydziałowy kurs bibliotekarski na KUL. Od 1957 r. współorganizował Ośrodek 
nizacji szkoleń, które służyłyby przygotowaniu fachowych kadr dla bibliotek kościelnych oraz wypracowaniu instrukcji dotyczących organizowania księgozbiorów. Pierwszy kurs dla bibliotekarzy kościelnych pod patronatem prymasa miał odbyć się w dniach 31 VIII - 30 IX 1953 r. w Krakowie. Sprawy administracyjne powierzono o. R. Gustawowi, zaś stroną naukową miał zając się Jan Baumgart z Biblioteki Jagiellońskiej. Podczas szkolenia miano przedstawić bibliotekarzom z kościelnych książnic zagadnienia księgoznawstwa, bibliotekoznawstwa, bibliotekarstwa i bibliografii ${ }^{2}$. Jednak z powodu sytuacji społeczno-politycznej w Polsce (m.in. 25 IX 1953 r. uwięziono prymasa S. Wyszyńskiego), planowany kurs nie odbył się.

W dwa lata później (1955) o. R. Gustaw powrócił do planów zorganizowania kursu bibliotecznego. Patronat nad zjazdem objął bp Michał Klepacz, przewodniczący Episkopatu Polski, w zastępstwie uwięzionego prymasa. Kurs odbył się w Bibliotece Uniwersyteckiej KUL, w dniach 16-22 VIII 1955 r. Celem szkolenia było zapoznanie uczestników z podstawowymi zasadami prowadzenia bibliotek kościelnych oraz nawiązanie współpracy w rozwiązywaniu bieżących problemów. W sesji wzięło udział kilkudziesięciu przedstawicieli bibliotek diecezjalnych i zakonnych. Na koniec obrad uczestnicy wysunęli postulat utworzenia przy Bibliotece KUL:

Ośrodka informacji i poradnictwa dla bibliotek kościelnych w całym kraju, którego zadaniem byłaby fachowa opieka nad nimi oraz troska o podnoszenie kwalifikacji zawodowych zatrudnionego w nich personelu ${ }^{3}$.

Senat KUL i Rektor ks. Józef Iwanicki, pozytywnie ustosunkowali się do postulatu, zwracając uwagę na ważność tego ośrodka dla środowiska kościelnego oraz KUL. Z polecenia rektora, o. R. Gustaw zwrócił się do Przewodniczącego Episkopatu Polski bpa M. Klepacza pismem z dnia 6 grudnia 1955 r., z prośbą o akceptację powstania w Bibliotece KUL ośrodka, w którym na jednym etacie zatrudniona miał być pracownik zajmujący się sprawami bibliotek kościelnych, znający również zasady nowoczesnego prowadzenia archiwów kościelnych ${ }^{4}$.

Ostatecznie o. R. Gustaw został zaproszony 27 sierpnia 1956 r. na posiedzenie plenarne Episkopatu Polski na Jasnej Górze. Zreferował tam sprawę organizacji Ośrodka Bibliotek i Archiwów Kościelnych. Przedstawił ułożony przez siebie Re-

Archiwów, Bibliotek i Muzeów Kościelnych; był członkiem redakcji „Encyklopedii Katolickiej” oraz półrocznika „Archiwa, Biblioteki i Muzea Kościelne”. Jest autorem m.in. Liber mortuorum polskich prowincji bernardynów od 1815 do 1940, zestawień bibliograficznych, Katalogu archiwum klasztoru sióstr bernardynek w Krakowie. B. Królikowski, Gustaw Romuald OFM, w: „Encyklopedia Katolicka", t. 6, red. J. Walkusz, Lublin 1993, kol. 406; W. Nowodworski, Stowo wstepne, „Archiwa Biblioteki i Muzea Kościelne” 23 (1971), s. 3-6; J. Nastalska-Wiśnicka, M. Trojnacka, Ojciec Romuald Gustaw: uczony-bibliotekarz-dyrektor-człowiek, w: W stużbie nauki, wartości $i$ wychowania. Szkice biograficzne o lubelskim środowisku naukowym, red. R. Skrzyniarz, M. Łobacz, B. Borowska, Lublin 2015, s. 185-214.

${ }^{2}$ M. Dębowska, Ośrodek Archiwów, Bibliotek i Muzeów Kościelnych Katolickiego Uniwersytetu Lubelskiego Jana Pawła II 1956-2006, Lublin 2006, s. 14-15.

${ }^{3}$ Tamże.

${ }^{4}$ Tamże, s. 17. 
gulamin wewnętrzny Biblioteki Uniwersyteckiej KUL. Dziat: Ośrodek Bibliotek i Archiwów Kościelnych. Postulował również uchwalenie comiesięcznych wpłat na jego funkcjonowanie: $50 \mathrm{zł} \mathrm{od} \mathrm{kurii} \mathrm{diecezjalnych} \mathrm{i} 100 \mathrm{zł} \mathrm{od} \mathrm{kurii} \mathrm{prowincjal-}$ nej. Propozycja spotkała się z akceptacją Episkopatu, który zatwierdził powstanie Ośrodka oraz wysokość wpłat ${ }^{5}$.

Konieczność powstania takiego ośrodka, była postulowana również przez uczestników kursu dla pracowników archiwów diecezjalnych i zakonnych, który odbył się w dniach 3-15 września 1956 r. Kurs został zorganizowany przez o. R. Gustawa, na prośbę Episkopatu Polski i przy wsparciu Naczelnej Dyrekcji Archiwów Państwowych ${ }^{6}$. Uczestnicy z zadowoleniem przyjęli oświadczenie o. R. Gustawa, który poinformował zebranych o zgodzie Episkopatu Polski na powstanie takiego ośrodka, jako działu Biblioteki KUL ${ }^{7}$.

Ostatecznie, 20 grudnia 1956 r. Senat KUL, na wniosek o. Gustawa, zatwierdził powstanie Ośrodka ABMK jako działu Biblioteki Uniwersyteckiej, mający za zadanie prowadzenie centralnej ewidencji archiwów i bibliotek kościelnych oraz organizację ich współpracy z Biblioteką Uniwersytecką KUL ${ }^{8}$. Nazwa Ośrodek Archiwów Bibliotek i Muzeów Kościelnych pojawiła się dopiero w styczniu 1957 r., w odezwie promującej pierwszy numer pisma Ośrodka. Kierownikiem nowej placówki został jezuita ks. Eugeniusz Reczek ${ }^{9}$.

${ }^{5}$ Ośrodek Archiwów Bibliotek i Muzeów Kościelnych (Ośrodek ABMK), „Archiwa Biblioteki i Muzea Kościelne” (dalej: ABMK), 1 (1959) z. 1, s. 12; Dębowska, Ośrodek Archiwów, Bibliotek i Muzeów Kościelnych, s. 14-19.

${ }^{6}$ Należy wspomnieć, że o. R. Gustaw 16 września 1955 r. został delegowany przez Episkopat Polski do rozmów z Naczelną Dyrekcją Archiwów Państwowych. Delegacja związana była z pismem NDAP skierowanego do Sekretariatu Episkopatu Polski, z propozycjami: 1. Rejestracji archiwów kościelnych, 2. przyjęcia i zastosowania wspólnych z archiwami państwowymi metod porządkowania i opisu archiwaliów, 3. ustalenie sposobu udostępniania materiałów archiwalnych, 4. współpracy w konserwacji materiałów archiwalnych. Dębowska, Ośrodek Archiwów, Bibliotek i Muzeów Kościelnych, s. 17.

${ }^{7}$ Dębowska, Ośrodek Archiwów, Bibliotek i Muzeów Kościelnych, s. 19-21; K. Wiśniowska, Kalendarium Biblioteki, ABMK, 23 (1971) s. 36.

${ }^{8}$ Dębowska, Ośrodek Archiwów, Bibliotek i Muzeów Kościelnych, s. 22. K. Wiśniowska, Kalendarium Biblioteki, s. 36.

${ }^{9}$ Eugeniusz Reczek - ur. 25 grudnia 1916 r. w Nowym Sączu, zm. 11 lutego 1971 r. w Grottaferrata k. Rzymu. W 1934 r. wstąpił do zakonu jezuitów, święcenia kapłańskie przyjął w 1950 r. Studia filozoficzne rozpoczął w 1938 r. w Krakowie, przerwane po wybuchu drugiej wojny światowej. W 1943 r. został wywieziony na roboty przymusowe do Niemiec. Po powrocie do kraju w 1945 r. ukończył studia filozoficzne (1945-1946) oraz studiował teologię w Lublinie (1946-1948) i Zakopanem (1948-1950). Po święceniach kapłańskich w 1950 r. pracował jako katecheta szkół średnich w Lublinie. Był współorganizatorem i pierwszym kierownikiem Ośrodka Archiwów Bibliotek i Muzeów Kościelnych przy KUL. Po koniec 1957 r. wyjechał do Rzymu w celu poszukiwań poloników w Archiwum i Bibliotece Watykańskiej. Był redaktorem czterech tomów „Sacrum Poloniae Millenium”. Założył Instytut Studiów Kościelnych w Rzymie. W 1965 r. rozpoczął wydawnictwo seryjne „Studia Ecclesiastica” oraz „Życie i Wiara”. L. Grzebień, Reczek Eugeniusz, w: Encyklopedia wiedzy o jezuitach na ziemiach Polski i Litwy. 1564-1995, Kraków 1996, s. 563564; M. Dębowska, Eugeniusz Reczek TJ-pierwszy kierownik Ośrodka Archiwów Bibliotek i Mu- 
Od początku powstania Ośrodka ABMK ścierały się dwie skrajne koncepcje dotyczące jego struktury i umiejscowienia. Pierwsza reprezentowana była przez o. R. Gustawa, który optował za powstaniem takiego ośrodka w Lublinie, jako działu Biblioteki Uniwersyteckiej. Podczas dyskusji 12 września 1956 r.:

[o. Romuald Gustaw - A.H.] podkreślił konieczność udostępniania zasobów archiwalnych, ponieważ przez to przysłużymy się nauce, a zwłaszcza nauce katolickiej. Celem bowiem tego ośrodka jest udostępnienie archiwaliów naukowcom. Konieczność opracowania historii Kościoła w Polsce domaga się całego szeregu opracowań monograficznych, które muszą być udokumentowane źródłami znajdującymi się w archiwach. Opracowanie tych prac ma miejsce na KUL-u, dlatego też złączenie ośrodka z tą uczelnią to sprawa nauki katolickiej. Dalszym argumentem to prace wydawnicze, które wymagają zaplecza księgozbioru i częstych konsultacji w tej dziedzinie. W związku z tym celem rola archiwum, biblioteki, a także muzeum łączą się. Nadrzędnym terminem tych dziedzin jest dokumentacja. Dlatego w pierwszym etapie tego rodzaju ośrodek powinien obejmować również muzea. Oczywiście z czasem rozwijając się, ten skromny ośrodek urośnie w odrębną wspaniałą instytucję nie złączoną z Biblioteką KUL ${ }^{10}$.

Za przeniesieniem ośrodka do Warszawy i oddanie go pod auspicjami Sekretariatu Polski, opowiadał się początkowo ks. S. Librowski, a potem dążył do tego kierownik ośrodka ks. E. Reczek ${ }^{11}$.

Ostatecznie, na podstawie zatwierdzonego przez Senat KUL regulaminu autorstwa o. R. Gustawa, Ośrodek ABMK został działem Biblioteki Uniwersyteckiej KUL. Jego kierownik był bezpośrednio zależny od dyrektora biblioteki. Musiał z nim uzgadniać plan pracy, prowadzić statystyki i przedkładać comiesięczne sprawozdania z wykonanych prac. Taka zależność szybko doprowadziła do dużych tarć między kierownikiem Ośrodka ABMK ks. E. Reczkiem, a dyrektorem Biblioteki KUL o. R. Gustawem. Skutkowało to paraliżem jego działalności, zakończonym dopiero wyjazdem za granicę kierownika Ośrodka ABMK ${ }^{12}$.

Ks. E. Reczek planował usamodzielnienie Ośrodka ABMK, poprzez podporządkowanie go bezpośrednio rektorowi KUL. W przygotowanym przez siebie statucie ośrodka, wzorując się na strukturze Biblioteki Narodowej, planował utworzenie 12 działów, składających się łącznie z 36 zakładów ${ }^{13}$. Przedstawiony

zeów Kościelnych, w: W stużbie nauki, wartości i wychowania. Szkice biograficzne o lubelskim środowisku naukowym, red. R. Skrzyniarz, M. Łobacz, B. Borowska, Lublin 2015, s. 215-233;

${ }^{10}$ Archiwum Ośrodka Archiwów Bibliotek i Muzeów Kościelnych (dalej: ArOABMK), t. Kurs dla archiwistów, Protokół z dyskusji.

${ }^{11}$ Dębowska, Eugeniusz Reczek TJ-pierwszy kierownik Ośrodka, s. 227-228; A. Hamryszczak, Między Włocławkiem a Lublinem - działalność naukowa i archiwalna ks. prof. Stanisława Librowskiego (1914-202), w: W stużbie nauki, wartości i wychowania. Szkice biograficzne o lubelskim środowisku naukowym, red. R. Skrzyniarz, M. Łobacz, B. Borowska, Lublin 2015, s. 237.

${ }^{12}$ M. Dębowska, Eugeniusz Reczek TJ, s. 223-225; taż, Statut ks. Eugeniusza Reczka SI dla Ośrodka Archiwów Bibliotek i Muzeów Kościelnych w Lublinie, w: Archiwa kościelne w stużbie społeczeństwu, red. M. Różański, Łódź 2014, s. 94-95.

${ }^{13}$ Dębowska, Eugeniusz Reczek TJ, s. 224; taż, Statut ks. Eugeniusza Reczka SI, s. 89-94. 
projekt został odrzucony przez Senat KUL, ze względu na brak możliwości realizacji tych założeń przez uniwersytet ${ }^{14}$.

W 1958 r. doszło do istotnych zmian organizacyjnych w Ośrodku ABMK, związanych z rozszerzeniem działalności o archiwistykę (ks. Stanisław Librowski) i muzealnictwo (ks. Władysław Smoleń). Rektor KUL, ks. Marian Rechowicz zwołał zebranie w dniu 22 października 1958 r. na temat opracowania nowego statutu Ośrodka ABMK, na podstawie projektu przygotowanego przez p.o. kierownika, W. Nowodworskiego. Rektor, ks. S. Librowski i ks. W. Smoleń byli zwolennikami wydzielenia Ośrodka ABMK ze struktury Biblioteki Uniwersyteckiej KUL. Natomiast jej przedstawiciele: o. R. Gustaw, który nie przybył na spotkanie, oraz W. Nowodworski, byli za utrzymaniem dotychczasowego stanu. Podczas spotkania zwyciężyła koncepcja przypisania Ośrodka ABMK bezpośrednio rektorowi jako uniwersyteckiego międzywydziałowego zakładu o charakterze naukowym i usługowym. W wyniku dalszych prac ustalono, że na czele Ośrodka ABMK będzie stał dyrektor mianowany przez rektora spośród profesorów uczelni (ks. Józef Rybczyk). W ośrodku stworzono działy, którymi kierowali referenci sekcji: archiwalnej (ks. S. Librowski), bibliotecznej (o. R. Gustaw - do †1976), muzealnej (ks. W. Smoleń) i bibliograficznej (W. Nowodworski). Pracę biura miał koordynować sekretarz naukowy Ośrodka ABMK. Pomimo wydzielenia Ośrodka z BU KUL, jego siedziba nadal pozostawała w gmachu książnicy ${ }^{15}$.

Według opinii ks. S. Librowskiego:

Ośrodek ABMK, wyzwalając się spod twardej ręki dyrektora Biblioteki, odetchnął z ulgą. Dostając się pod „szeroką” jurysdykcję rektora Uczelni, wypływał na rozleglejsze wody ${ }^{16}$.

Senat KUL zatwierdził statut Ośrodka Archiwów Bibliotek i Muzeów Kościelnych w dniu 25 czerwca 1959 r. ${ }^{17}$

R. Gustaw był inicjatorem i faktycznym założycielem pisma „Archiwa Biblioteki i Muzea Kościelne”. Jednak to ks. S. Librowski powszechnie jest uważany za twórcę pisma, ze względu na fakt, że udało mu się doprowadzić do wydania drukiem pierwszego tomu periodyku. Dodatkowo od tomu 38 z 1979 r. półrocznika tytułował się ,redaktorem założycielem”.

Plan wydawania własnego biuletynu przez Ośrodek ABMK, zawarty był w regulaminie przygotowanym przez o. Gustawa. Celem pisma, które miało ukazywać się regularnie co dwa miesiące miało być utrzymanie kontaktu z bibliotekami i archiwami kościelnymi ${ }^{18}$. Zgodnie ze statutem Ośrodka ABMK, pismo

${ }^{14}$ Taż, Ośrodek Archiwów, Bibliotek i Muzeów Kościelnych, s. 26.

${ }^{15}$ Tamże, s. 28-30.

${ }^{16} \mathrm{~S}$. Librowski, Kalendarium życia, cierpień, działalności, twórczości i uznania księdza Stanistawa Librowskiego, ABMK, 58 (1989) s. 269-550.

${ }^{17}$ Statut Ośrodka Archiwów Bibliotek i Muzeów Kościelnych przy Katolickim Uniwersytecie Lubelskim, w: ABMK, 1 (1960) z. 2, s. 5-7; Ośrodek Archiwów Bibliotek i Muzeów Kościelnych (Ośrodek ABMK), s. 16-17; Wiśniowska, Kalendarium Biblioteki, s. 38.

${ }^{18}$ ArOABMK, t. Organizacja, Regulamin wewnętrzny Biblioteki Uniwersyteckiej KUL opracowany przez o. Romualda Gustawa w 1956 r. i zaprezentowany na Plenarnej Konferencji Episkopatu Polski w Częstochowie 27 sierpnia 1956 r. 
miało również informować o podejmowanych przez Ośrodek ABMK pracach i ich wynikach oraz przekazywać wytyczne w dziedzinie organizacji archiwów i bibliotek kościelnych. Do zadań pisma należało także upowszechnianie informacji z życia instytucji kościelnych przechowujących zbiory kulturowe Kościoła katolickiego w Polsce ${ }^{19}$.

W dniu 7 marca 1957 r. o. R. Gustaw wystosował pismo do Wojewódzkiego Urzędu Kontroli Prasy, Publikacji i Widowisk w Lublinie o zgodę na wydawanie dwumiesięcznika „Biuletyn Informacyjny”, jako organu wydawniczego Ośrodka Archiwów Bibliotek i Muzeów Kościelnych". Pismo miało ukazywać w technice powielaczowej, mieć objętość od 20 do 50 stron, format A-4 i nakład 500 egzemplarzy. Władze pismem z 21 marca 1957 r. wyraziły zgodę na wydawanie wspomnianego pisma ${ }^{20}$. Ponieważ w międzyczasie zmieniła się koncepcja pisma, 8 czerwcu 1957 r. ks. E. Reczek, złożył podanie do władz państwowych o zgodę na wydawanie przez Ośrodek ABMK kwartalnika „,Biuletyn Informacyjny Ośrodka Archiwów Bibliotek i Muzeów Kościelnych” o objętości 200 stron i nakładzie 450 egzemplarzy. Podobne pismo wystosował dnia 31 maja 1957 r. ks. Stanisław Librowski ${ }^{21}$, dyrektor Archiwum Diecezjalnego we Włocławku, który chciał wy-

${ }^{19}$ Statut Ośrodka Archiwów Bibliotek i Muzeów Kościelnych, s. 5-7; A. Hamryszczak, Pótrocznik „Archiwa Biblioteki i Muzea Kościelne' (1959-2010), w: Czasopisma naukowe bibliotek, archiwów, muzeów. Tradycje-role-perspektywy, red. A. Królczyk, Kórnik 2010, s. 163-164; tenże, Pólrocznik „, Archiwa Biblioteki i Muzea Kościelne”. Przeszłość-teraźniejszość-przyszłość, s. 5-6.

${ }^{20}$ Dębowska, Ośrodek Archiwów Bibliotek i Muzeów Kościelnych, s. 103.

${ }^{21}$ Ks. Stanisław Librowski - ur. 26 kwietnia 1914 r. w Krzemieniewicach, zm. 23 listopada 2002 r. we Włocławku. W 1931 r. rozpoczął naukę w Niższym Seminarium Duchownym (Liceum im. Piusa X) we Włocławku, zwieńczoną uzyskaniem świadectwa dojrzałości w 1935 r. Tego samego roku wstąpił do Wyższego Seminarium Duchownego we Włocławku. Po wybuchu II wojny światowej został aresztowany wraz z innymi duchownymi Włocławka w dniu 7 listopada 1939 r. Po pobycie w licznych więzieniach i obozach koncentracyjnych, ostatecznie został umieszczony w obozie w Dachau. Po wyzwoleniu obozu, ukończył studia teologiczne w Francji, gdzie przyjął święcenia kapłańskie 29 lipca 1945 r. W 1946 r. objął w administrację parafię Michelin. W 1947 r. został mianowany kierownikiem Archiwum Diecezjalnego we Włocławku. W latach 1946-1948 studiował historię na Uniwersytecie Warszawskim. W 1948 r. uzyskał tytuł magistra teologii w zakresie historii Kościoła, na podstawie pracy Kapituła katedralna we Włocławku, napisanej na seminarium ks. prof. Zdzisława Obertyńskiego. W 1951 r. ks. S. Librowski uzyskał tytuł naukowy doktora na podstawie pracy Hieronim Rozdrażewski, biskup kujawski i pomorski. Od 1958 r. podjął pracę na KUL, m.in. w Ośrodku ABMK, a po uzyskaniu habilitacji kierował Katedrą Metodologii i Nauk Pomocniczych Historii Kościoła. W 1964/1965 uzyskał habilitację na Uniwersytecie Warszawskim przedstawiając rozprawę Wizytacje diecezji kujawskiej i pomorskiej, zatwierdzoną przez władze państwowe w 1966 r. W 1970 r. Ministerstwo Oświaty i Szkolnictwa Wyższego zatwierdziło tytuł profesora nadzwyczajnego, a w 1975 zwyczajnego. Ks. S. Librowski był założycielem i redaktorem czasopisma „Archiwa Biblioteki i Muzea Kościelne” w latach 1959-1991, wydając 60 tomów półrocznika. M. Zahajkiewicz, Librowski Stanistaw, w: Encyklopedia katolicka, t. 10, red. A. Szostek, Lublin 2004, kol. 985-986; tenże, Ksiadz profesor dr hab. Stanisław Librowski (1914-2002), badacz przeszłości i uczony zastużony dla archiwistyki kościelnej, ABMK, 79 (2003) s. 13-18; W. Kujawski, Ks. prof. Stanisław Librowski. Archiwista, historyk, redaktor, „Studia Włocławskie”, 2 (1999) s. 7-17; J. Szymański, Librowski Stanisław, w: Duszpasterze Polonii i Polaków za granica, t. 1, Lublin 2010, s. 93-94; M. Dębowska, Wktad księdza profesora Stanistawa Librowskiego w powstanie, 
dawać półrocznik „Archiwa Kościelne”. Ponieważ władze nie wydawały wówczas zgody na pisma o podobnym profilu, obydwaj wnioskodawcy uzgodnili, że razem będą wydawać pismo „Archiwa Biblioteki i Muzea Kościelne”. Działem archiwistyki kościelnej kierować miał ks. S. Librowski ${ }^{22}$. Pismem z dnia 28 czerwca 1957 r. Ośrodek ABMK otrzymał od Głównego Urzędu Kontroli Prasy, Publikacji i Widowisk w Warszawie pozwolenie na wydanie wnioskowanego pisma w formacie B5, objętości 200 stron, nakładzie 650 egzemplarzy i kwartalną częstotliwością ukazywania się ${ }^{23}$.

Podczas zjazdu archiwistów, bibliotekarzy i muzeologów kościelnych w dniach 26-27 czerwca 1957 r. o. Gustaw poinformował zebranych o uzyskaniu zgody władz państwowych na wydawanie kwartalnika przez Ośrodek ABMK i potwierdził prace nad ukazaniem się pierwszego numeru pisma „Archiwa Biblioteki i Muzea Kościelne"24.

Zamiaru tego nie udało się jednak zrealizować przez prawie dwa lata co groziło nawet odebraniem przez władze państwowe licencji wydawniczej. Jednym z powodów opóźnienia druku, były ciągłe zmiany personalne w Ośrodku ABMK. Artykuły naukowe do pisma zbierał każdorazowy kierownik Ośrodka. W grudniu 1957 r. wyjechał za granicę ks. E. Reczek. Dlatego wydanie pisma rektor KUL zlecił kustoszowi W. Nowodworskiemu (od 1 III 1958 p.o. kierownika ABMK). Dopiero jednak po objęciu funkcji kierownika ABMK przez ks. S. Librowskiego w dniu 15 października 1958 r., sprawa wydania kwartalnika zakończyła się pomyślnie. Pomimo tego, że na stałe mieszkał we Włocławku, udało mu się skompletować artykuły do pierwszego numeru pisma. Dodatkowo zaradził podstawowemu problemowi z którym zmagał się o. R. Gustaw, który wprawdzie uzyskał od władz państwowych przydział papieru, ale nie mógł znaleźć drukarni, która przyjęłaby zlecenie wydania pisma. Ks. S. Librowski bez problemów złożył 30 października 1958 r. do druku pierwszy zeszyt pisma „Archiwa Biblioteki i Muzea Kościelne” we Włocławskich Zakładach Przemysłu Terenowego. Była to znacjonalizowana drukarnia diecezjalna, stąd też kierownictwo oraz pracownicy zakładu wyrażali przychylność inicjatywom wydawniczym Kościoła ${ }^{25}$. Druk pierwszego egzemplarza został ukończony w czerwcu 1959 r. Jego okładkę zaprojektował Jan Przełomiec z KUL.

organizacje i realizację zadań statutowych Ośrodka Archiwów Bibliotek i Muzeów Kościelnych, „Studia Włocławskie”, 10 (2007) s. 53-61.

${ }^{22}$ A. Hamryszczak, Ksiądz Stanistaw Librowski. Redaktor-założyciel pótrocznika „,Archiwa Biblioteki i Muzea Kościelne”, w: Ksiądz Stanisław Librowski archiwista, historyk Kościoła i dydaktyk, red. D. Kiper, W.W. Żurek, Lublin 2015, s. 33-34; tenże, „,Archiwa Biblioteki i Muzea Kościelne”. Pismo Ośrodka Archiwów Bibliotek i Muzeów Kościelnych, w: Czasopisma archiwów, bibliotek i muzeów Kościoła katolickiego, red. W. Żurek, Lublin 2014, s. 49, 51-52.

${ }^{23}$ Dębowska, Ośrodek Archiwów, Bibliotek i Muzeów Kościelnych, s. 104; Hamryszczak, Pótrocznik „Archiwa, Biblioteki i Muzea Kościelne” (1959-2010), s. 164; tenże, Pótrocznik „Archiwa Biblioteki i Muzea Kościelne”. Przeszłość - teraźniejszość - przyszłość, s. 7.

${ }^{24}$ Pierwszy zjazd archiwistów, bibliotekarzy i muzeologów kościelnych, ABMK, 1 (1959) z. 1, s. 19.

${ }^{25}$ Librowski, Kalendarium życia, cierpień, działalności, twórczości i uznania, s. 477. 
Nowo powstałe pismo składało się zasadniczo z pięciu działów: I. Rozprawy, II. Z życia archiwów, bibliotek i muzeów kościelnych, III. Notatki informacyjne i recenzje, IV. Bibliografia, V. Materiały źródłowe ${ }^{26}$.

Redakcja w słowie wstępnym napisała:

Służąc archiwom, bibliotekom i muzeom kościelnym, niechaj ono przyczyni się chociaż w skromnej mierze do uporządkowania tych zbiorów i wydobycia ich z nich źródeł do poznania historii i kultury polskiej i katolickiej. Redakcja żywi nadzieję, że czasopismo, jako pierwsze u nas w tym przedmiocie, zostanie przyjęte przez czytelników z dużym wyrozumieniem i z należytym poparciem ${ }^{27}$.

Trzy początkowe tomy ABMK, były wydawane co kwartał, jednak ze względu na ingerencję cenzury w treść pisma oraz ze zbyt małej liczby pracowników, kierownictwo Ośrodka ABMK zdecydowało się na półroczny cykl wydawniczy. Od 1962 r. „Archiwa Biblioteki i Muzea Kościelne” ukazują się jako półrocznik o objętości 400 stron $^{28}$.

W skład komitetu redakcyjnego pierwszego tomu pisma „Archiwa Biblioteki i Muzea Kościelne” wchodzili: ks. Stanisław Librowski - redaktor naczelny, Witold Nowodworski, ks. Józef Rybczyk i ks. Władysław Smoleń. Natomiast o. Romuald Gustaw został wpisany jako współpracownik pisma, razem siedmioma innymi uczonymi. Od tomu 2 (1961) z. 1-2, komitet redakcyjny pisma przedstawiał się następująco: ks. S. Librowski - redaktor naczelny, ks. J. Rybczyk - dyrektor Ośrodka ABMK (do tomu 36 z 1978 r.), ks. W. Smoleń (do tomu 55 z 1987 r.), W. Nowodworski (do tomu 27 z 1972 r.) oraz o. R. Gustaw (do rezygnacji w 1973 r.; ostatni tom - 26 z 1972 r.).

Na łamach ABMK, o. R. Gustaw opublikował tylko cztery artykuły (w tym dwa jako współautor). W pierwszym numerze zamieszczono referaty wygłoszone podczas zjazdu archiwistów, bibliotekarzy i muzeologów kościelnych na Jasnej Górze w 1957 r., wśród nich wystąpienie o. Gustawa: Stan i potrzeby bibliotek kościelnych oraz program pracy na najbliższy okres ${ }^{29}$. Ponadto razem z Kazimierzem Kaczmarczykiem opublikował Katalog Archiwum Klasztoru Sióstr Bernardynek przy kościelne św. Józefa $w$ Krakowie ${ }^{30}$, a z Witoldem Nowodworskim artykuł Dwadzieścia lat Biblioteki Uniwersyteckiej KUL (1939-1958) ${ }^{31}$. Ostatni artykuł Rola i znaczenie Biblioteki, o. R. Gustaw umieścił w tomie 23 (1971)

\footnotetext{
${ }^{26}$ Od Redakcji, ABMK, 1 (1959) z. 1, s. 7.

${ }^{27}$ Tamże, s. 9.

${ }^{28}$ Hamryszczak, ,Archiwa Biblioteki i Muzea Kościelne”. Pismo Ośrodka Archiwów Bibliotek i Muzeów Kościelnych, s. 50-51; tenże, Ksiadz Stanisław Librowski. Redaktor-założyciel pótrocznika, s. 36.

${ }^{29}$ R. Gustaw, Stan i potrzeby bibliotek kościelnych oraz program pracy na najbliższy okres, ABMK, 1 (1959) z. 1, s. 34-43.

${ }^{30}$ R. Gustaw, K. Kaczmarczyk, Katalog Archiwum Klasztoru Sióstr Bernardynek przy kościelne św. Józefa w Krakowie, ABMK, 20 (1970) s. 5-94.

${ }^{31}$ R. Gustaw, W. Nowodworski, Dwadzieścia lat Biblioteki Uniwersyteckiej KUL (1939-1958), ABMK, 1 (1960) z. 2, s. 133-160.
} 
ABMK. Wspomniany tom był dedykowany jego osobie z okazji 60. rocznicy urodzin i 20-lecia pracy na stanowisku dyrektora Biblioteki Uniwersyteckiej KUL.

Numer ten ma nieocenioną wartość do zaznajomienia się z dorobkiem naukowym i organizacyjnym o. Gustawa ${ }^{32}$. Zmieszczono w nim m.in. bibliografię jego prac $^{33}$ oraz sprawozdanie z uroczystości dwudziestolecia pracy w Bibliotece Uniwersyteckiej KUL. W tomie umieszczono również blok artykułów Biblioteka Uniwersytecka Katolickiego Uniwersytetu Lubelskiego 1918-1970, autorstwa pracowników tej książnicy ${ }^{34}$. Na ich podstawie można stwierdzić, że 20-letnia praca o. Gustawa była bardzo owocna dla kierowanej przez niego biblioteki. Wypracowana przez niego koncepcja Biblioteki Uniwersyteckiej KUL, wyszła poza ramy instytucji służącej tylko jednej uczelni. Stała się ona główną i najważniejszą książnicą w Polsce specjalizującą się w gromadzeniu piśmiennictwa z zakresu teologii i filozofii chrześcijańskiej oraz prowadząca działalność dokumentacyjną w zakresie krajowego piśmiennictwa teologiczno-filozoficznego. Jednocześnie stała się wzorcową biblioteką Kościoła katolickiego w Polsce, stanowiąc punkt odniesienia dla innych książnic kościelnych. O. Gustaw zabiegał aby pracownicy Biblioteki KUL, nabywali potrzebne umiejętności i wykształcenie, zdobywając kolejne stopnie biblioteczne. Dzięki temu książnica mogła prowadzić we współpracy z Ośrodkiem ABMK, profesjonalne szkolenia dla pracowników bibliotek i przyszłych adeptów bibliotekarstwa z książnic kościelnych.

Podsumowaniem artykułu mogą być słowa o. R. Gustawa, które wypowiedział podczas swojego jubileuszu:

ważne jest uświadomienie sobie przemijania i wartości czasu; tego, że liczy się

w życiu to, jak wykorzystaliśmy czas nam dany i co po nas zostaje ${ }^{35}$.

Słowa kluczowe: Biblioteka Uniwersytecka KUL, Ośrodek Archiwów Bibliotek i Muzeów Kościelnych, półrocznik „Archiwa Biblioteki i Muzea Kościelne, o. Romuald Gustaw OFM, kursy biblioteczne

${ }^{32}$ R. Gustaw, Rola i znaczenie Biblioteki, ABMK, 23 (1971) s. 21-29.

${ }^{33}$ J. Styk, Bibliografia prac doc. dra hab. o. Romualda Gustawa OFM, ABMK, 23 (1971) s. 7-10.

${ }^{34}$ Biblioteka Uniwersytecka Katolickiego Uniwersytetu Lubelskiego 1918-1970, ABMK, 23 (1971) s. 19-212.

${ }^{35}$ Sprawozdanie z uroczystości dwudziestolecia pracy o. R. Gustawa na stanowisku dyrektora Biblioteki Uniwersyteckiej KUL, ABMK, 23 (1971) s. 14 


\section{BIBLIOGRAFIA}

\section{Źródła}

Archiwum Ośrodka Archiwów Bibliotek i Muzeów Kościelnych (ArOABMK)

t. Kurs dla archiwistów, Protokół z dyskusji.

t. Organizacja, Regulamin wewnętrzny Biblioteki Uniwersyteckiej KUL opracowany przez o. Romualda Gustawa w 1956 r. i zaprezentowany na Plenarnej Konferencji Episkopatu Polski w Częstochowie 27 sierpnia 1956 r.

Statut Ośrodka Archiwów Bibliotek i Muzeów Kościelnych przy Katolickim Uniwersytecie Lubelskim, „Archiwa Biblioteki i Muzea Kościelne”, 1 (1960) z. 2, s. 5-7

\section{Opracowania}

Biblioteka Uniwersytecka Katolickiego Uniwersytetu Lubelskiego 1918-1970, „Archiwa Biblioteki i Muzea Kościelne”, 23 (1971) s. 19-212.

Dębowska Maria, Eugeniusz Reczek TJ - pierwszy kierownik Ośrodka Archiwów Bibliotek i Muzeów Kościelnych, w: W służbie nauki, wartości i wychowania. Szkice biograficzne o lubelskim środowisku naukowym, red. R. Skrzyniarz, M. Łobacz, B. Borowska, Lublin 2015, s. 215-233.

Dębowska Maria, Ośrodek Archiwów Bibliotek i Muzeów Kościelnych Katolickiego Uniwersytetu Lubelskiego Jana Pawła II 1956-2006, Lublin 2006.

Dębowska Maria, Statut ks. Eugeniusza Reczka SI dla Ośrodka Archiwów Bibliotek i Muzeów Kościelnych w Lublinie, w: Archiwa kościelne w służbie społeczeństwu, red. M. Różański, Łódź 2014, s. 85-104.

Dębowska Maria, Wkład księdza profesora Stanisława Librowskiego w powstanie, organizacje i realizację zadań statutowych Ośrodka Archiwów Bibliotek i Muzeów Kościelnych, „Studia Włocławskie”, 10 (2007) s. 53-61.

Grzebień Ludwik, Reczek Eugeniusz, w: Encyklopedia wiedzy o jezuitach na ziemiach Polski i Litwy. 1564-1995, Kraków 1996, s. 563-564.

Gustaw Romuald, Kaczmarczyk Kazimierz, Katalog Archiwum Klasztoru Sióstr Bernardynek przy kościelne św. Józefa w Krakowie, „Archiwa Biblioteki i Muzea Kościelne", 20 (1970) s. 5-94.

Gustaw Romuald, Nowodworski Witold, Dwadzieścia lat Biblioteki Uniwersyteckiej KUL (1939-1958), „Archiwa Biblioteki i Muzea Kościelne”, 1 (1960) z. 2, s. 133 160.

Gustaw Romuald, Rola i znaczenie Biblioteki, „Archiwa Biblioteki i Muzea Kościelne”, 23 (1971) s. 21-29.

Gustaw Romuald, Stan i potrzeby bibliotek kościelnych oraz program pracy na najbliższy okres, „Archiwa Biblioteki i Muzea Kościelne”, 1 (1959) z. 1, s. 34-43.

Hamryszczak Artur, Miedzy Włocławkiem a Lublinem - działalność naukowa i archiwalna ks. prof. Stanisława Librowskiego (1914-202), w: W służbie nauki, wartości i wychowania. Szkice biograficzne o lubelskim środowisku naukowym, red. R. Skrzyniarz, M. Łobacz, B. Borowska, Lublin 2015, s. 235-254.

Hamryszczak Artur, „Archiwa Biblioteki i Muzea Kościelne”. Pismo Ośrodka Archiwów Bibliotek i Muzeów Kościelnych, w: Czasopisma archiwów, bibliotek i muzeów Kościoła katolickiego, red. W. Żurek, Lublin 2014, s. 47-65.

Hamryszczak Artur, Ksiądz Stanisław Librowski. Redaktor-założyciel półrocznika „Archiwa Biblioteki i Muzea Kościelne”, w: Ksiądz Stanisław Librowski archiwista, historyk Kościoła i dydaktyk, red. D. Kiper, W.W. Żurek, Lublin 2015, s. 33-47. 
Hamryszczak Artur, Półrocznik „Archiwa Biblioteki i Muzea Kościelne’ (1959-2010), w: Czasopisma naukowe bibliotek, archiwów, muzeów. Tradycje-role-perspektywy, red. A. Królczyk, Kórnik 2010, s. 163-168.

Królikowski Bohdan, Gustaw Romuald OFM, w: „Encyklopedia Katolicka”, t. 6, red. J. Walkusz, Lublin 1993, kol. 406.

Kujawski Witold, Ks. prof. Stanisław Librowski. Archiwista, historyk, redaktor, „Studia Włocławskie", 2 (1999) s. 7-17.

Librowski Stanisław, Kalendarium życia, cierpień, działalności, twórczości i uznania księdza Stanisława Librowskiego, „Archiwa Biblioteki i Muzea Kościelne”, 58 (1989) s. $269-550$.

Nastalska-Wiśnicka Joanna, Trojnacka Małgorzata, Ojciec Romuald Gustaw: uczony-bibliotekarz-dyrektor-człowiek, w: W służbie nauki, wartości i wychowania. Szkice biograficzne o lubelskim środowisku naukowym, red. R. Skrzyniarz, M. Łobacz, B. Borowska, Lublin 2015, s. 185-214.

Nowodworski Witold, Słowo wstępne, „Archiwa Biblioteki i Muzea Kościelne”, 23 (1971), s. 3-6.

Od Redakcji, „Archiwa Biblioteki i Muzea Kościelne”, 1 (1959) z. 1, s. 7.

Ośrodek Archiwów Bibliotek i Muzeów Kościelnych (Ośrodek ABMK), „Archiwa Biblioteki i Muzea Kościelne", 1 (1959) z. 1, s. 10-17.

Pierwszy zjazd archiwistów, bibliotekarzy i muzeologów kościelnych, „Archiwa Biblioteki i Muzea Kościelne", 1 (1959) z. 1, s. 18-20.

Sprawozdanie z uroczystości dwudziestolecia pracy o. R. Gustawa na stanowisku dyrektora Biblioteki Uniwersyteckiej KUL, „Archiwa Biblioteki i Muzea Kościelne”, 23 (1971) s. 10-15.

Styk Józef, Bibliografia prac doc. dra hab. o. Romualda Gustawa OFM, 23 (1971) s. 7-10.

Szymański Józef, Librowski Stanisław, w: Duszpasterze Polonii i Polaków za granicą, t. 1, Lublin 2010, s. 93-94.

Wiśniowska Kazimiera, Kalendarium Biblioteki, „Archiwa Biblioteki i Muzea Kościelne", 23 (1971) s. 29-43.

Zahajkiewicz Marek T., Ksiądz profesor dr hab. Stanisław Librowski (1914-2002), badacz przeszłości i uczony zasłużony dla archiwistyki kościelnej, „Archiwa Biblioteki i Muzea Kościelne", 79 (2003), s. 13-18.

Zahajkiewicz Marek T., Librowski Stanisław, w: Encyklopedia katolicka, t. 10, red. A. Szostek, Lublin 2004, kol. 985-986. 


\title{
FR ROMUALD GUSTAW OFM - THE FOUNDER OF THE INSTITUTE OF CHURCH ARCHIVES, LIBRARIES AND MUSEUMS
}

\begin{abstract}
Summary
Fr Romuald Gustaw OFM, a long-time Director of the Catholic University of Lublin (KUL) Library, inspired the creation of the Institute of Church Archives, Libraries and Museums. Due to his competence, at the request of Cardinal Stefan Wyszyński, he organized training courses for employees of church libraries. Then the decision was also made to establish an institute (attached to the KUL Library), which could deal with church libraries, and eventually archives and museums. In 1956, Fr R. Gustaw presented the project of creating such an institute to the Polish Episcopate. On 20 December 1956, the authorities of the Catholic University of Lublin, at his request, approved the creation of the Institute of Church Archives, Libraries and Museums as a department of the KUL Library. In 1958, after the institute had become an independent centre, Fr R. Gustaw was appointed as manager of the library section; and he held this function until his death.

In 1957, he was the initiator of creating the journal of the institute „Archiwa Biblioteki i Muzea Kościelne”. In the years 1961-1972, he was a member of the editorial board. The volume 23 of 1971 was dedicated to Fr R. Gustaw on the occasion of the 60th anniversary of his birth and 20 years of his work as the Director of the KUL Library.
\end{abstract}

Keywords: the KUL Library, the Institute of Church Archives, Libraries and Museums, semi-annual journal "Archiwa Biblioteki i Muzea Kościelne”, Fr Romuald Gustaw OFM, library courses 